\title{
THE ACCEPTABILITY OF RHETORICAL QUESTION TRANSLATION IN FIVE ON A TREASURE ISLAND BY ENID BLYTON
}

\author{
PathyYulinda $^{a^{*}}$, Mangatur Rudolf Nababan ${ }^{b^{*}}$, Djatmika $^{c^{*}}$ \\ ${ }^{a}$ Department of Linguistics, University of Sebelas Maret \\ Jl. Ir. Sutami 36 A Kentingan, Surakarta, Indonesia \\ ${ }^{\mathrm{b}}$ Department of Linguistics, University of Sebelas Maret \\ Jl. Ir. Sutami 36 A Kentingan, Surakarta, Indonesia \\ ${ }^{c}$ Department of Linguistics, University of Se belas Maret \\ Jl. Ir. Sutami 36 A Kentingan, Surakarta, Indonesia \\ *pathy_yulinda@yahoo.co.id \\ *amantaradja@yahoo.com \\ *djatmika@uns.ac.id
}

\begin{abstract}
Abstrak: Penelitian ini bertujuan untuk mengidentifikasi fungsi pertanyaan retoris dan mendeskripsikan kualitas terjemahan, khususnya pada tingkat keberterimaan dalam novel Five On A Treasure Island karya Enid Blyton dan terjemahannya dalam bahasa Indonesia Lima Sekawan Di Pulau Harta yang diterjemahkan oleh Agus Setiadi. Metode penelitian yang digunakan yaitu kualitatif deskriptif melalui analisis konten dan focus group discussion (FGD). Hasil temuan pada penelitian ini terdapat 14 fungsi pertanyaan retoris dari 177 data yang ditemukan, yaitu memastikan (71 data), menunjukkan rasa heran/kaget (36 data), menekankan fakta yang sudah diketahui (12 data), menyarankan (11 data), mengajak (10 data), menunjukkan keragu-raguan/ketidakpastian (8 data), menunjukkan kekaguman ( 8 data), memerintah ( 6 data), meminta (4 data), menunjukkan rasa marah (3 data), menunjukkan kebingungan (3 data), mengeluh ( 2 data), memperkenalkan topic baru (2 data), dan mengingatkan (1 data). Terdapat 9 fungsi baru pertanyaan retoris yang ditemukan dalam penelitian ini yang sebelumnya belum disebutkan oleh Larson (1998) dan hasil FGD menunjukkan bahwa kualitas terjemahan pertanyaan retoris, khususnya tingkat keberterimaan, menghasilkan terjemahan dengan kualitas yang cukup baik atau berterima. Hasil penelitian ini menunjukkan bahwa pertanyaan retoris merepresentasikan banyak fungsi dalam sebuah percakapan dan untuk penerjemah, dalam menerjemahkan pertanyaan retoris sebaiknya memahami maksud pertanyaan retoris pada teks bahasa sumber dengan baik.
\end{abstract}

Kata kunci: pertanyaan retoris, penerjemahan, kualitas terjemahan, keberterimaan

Abstract: This study aims to identify the functions of rhetorical questions and to describe the quality of the translation in terms of acceptability on the novel of Five On A Treasure Island by Enid Blyton and its Indonesian translation Lima Sekawan Di Pula Harta translated by Agus Setiadi. The research method used in this study was descriptive qualitative with content analysis and focus group discussion (FGD).The findings were: there are 14 functions of rhetorical questions from 177 identified data, namely: to confirm (71 data), to show surprise (36 data), to emphasize a known fact (12 data), to suggest (11 data), to persuade (10 data), to show uncertainty ( 8 data), to show amazement ( 8 data), to 
command ( 6 data), to request ( 4 data), to show anger (3 data), to show confusion (3 data), to complain ( 2 data), to introduce a new topic ( 2 data), and to admonish (1 data). There are 9 new functions of rhetorical questions that have not been identified from Larson's concept (1998); and the FGD shows the quality of rhetorical questions translation in terms of the acceptability of the novel as high. In addition, rhetorical questions represent many functions in the conversation; therefore, the translator should carefully expose the intention of rhetorical questions in the source text.

Keywords: rhetorical questions, translation, quality of translation, acceptability

\section{INTRODUCTION}

The main function of a question is the speaker asking information to the hearer where the speaker does not know about that information. However, the question is not only used for asking information to the hearer. A question can be used for asking someone to do something or even making a statement, for example, "can you bring this box?" or "how can you believe him?". The respond of the expression "can you bring this box?" is not in the form of "yes, I can" or "no, I can't". Therefore as we can see from the previous example, the speaker used the question form for asking someone to do something; the speaker does not expect the answer from the hearer. The question that used for not asking information to the hearer is recognized as rhetorical question. Larson (1998: 257) states that rhetorical questions are not real questions; they are question forms used with a purpose other than to ask for information.

This study uses the novel of Five On A Treasure Island by Enid Blyton and its Indonesian translation Lima Sekawan Di Pulau Harta translated by Agus Setiadi as source of data. The genre of the novel is a mystery and adventure novel. There are many conversations in the novel which are in question form and the researcher found that there are some questions which are translated in declarative sentence form. Later, the novel and its translation can be analysis through the context of situation and the form of its translation. This study focuses on the question form in the novel and its translation. The aims of the study are to identify the function of rhetorical questions based on Larson's concept (1998) and to describe the quality of translation in terms of acceptability level based on the instrument of translation quality by Nababan, Nuraeni, and Sumardiono (2012).

Translating a rhetorical question can be misunderstanding if the translator cannot get the meaning of rhetorical question in the source text. It is also explained by Larson (1998: 259), that in preparing for translation, it may be very helpful for the translator to first study the functions of rhetorical questions in the source language and then in the receptor language. The functions need to be identified, but it is also important to focus on the form, since different forms may have different secondary functions. Translation consists of transferring the meaning of the source language into the receptor language (Larson, 1998: 3). Through the statement, Larson implies that the concept of translation is about the transferring of the meaning. The meaning of the source text should be same in the meaning of the target text, but the form can be changed. In translating a text, the translator is very affected by the language competency that they have. The language competency that the translator has will impact to the translation. If a translator have a high language competency to the source language and the target language, then the translation can be done quickly and produce high quality translation. Conversely, if a translator has a low language competency to the source language and the target language, then the translation cannot be done quickly and produce low quality translation (Nababan, 2008: 24).

A number of other relevant studies about questions translation were carried out. The using 
of questiontypes from the source text to the target text in the novel Pride and Prejudice and classifying the question types based on the answer way by Quirk (1985), namely: yes-no question, wh question, and alternative question. The study also describes the acceptability and unacceptability aspects in its Indonesian translation using intra lingual method (Arfani, 2016). Other studies relating to rhetorical question, there is a study that describes the examples of rhetorical question in the New Testament of Bible. The study explains a number of points that the translator should be noticed in translating the rhetorical questions in the New Testament of Bible (Ellingworth, 2013). Last, the study of rhetorical question translation is conducted by Al-Faddain his thesis, which was published by King Saud University in the year 2010. The study investigates the possibility of achieving functional equivalence when translating rhetorical questions in Hadith from Arabic into English. The study uses a linguistic approach which was based on Mousa's levels of rhetorical questions (1995), namely: the syntactic, semantic, pragmatic, and aesthetic levels.

Different from the previous studies, this study attempts to identify the function of rhetorical questions based on Larson's concept (1998) and to describe the quality of translation in terms of the acceptability level based on the instrument of translation quality by Nababan., et al (2012) in Five On A Treasure Island by Enid Blyton and its Indonesian translation Lima Sekawan Di Pulau Harta translated by AgusSetiadi.

\section{METHODOLOGY}

This is a qualitative descriptive research based on case study method. Source of data is the novel of Five On A Treasure Island by Enid
Blyton as the source text, Indonesian translation Lima Sekawan Di Pulau Harta translated by Agus Setiadi as the target text and informant (translation quality rater). The data are taken by analyzing a document, focus group discussion, and questioner. Analyzing a document is a characteristic of qualitative research (Moleong, 2005). Yin in Sutopo (2006: 81) states that analyzing a document is the way to find out various things which appropriately to the need and the purpose of research. Focus group discussion and questioner are used to discuss about the translation technique applied in translating the rhetorical questions and the translation quality in regarding the acceptability.

The process of analyzing the document, as follow: reading the novel and its Indonesian translation, analyzing a question form based on the context of situation, identifying a question form into rhetorical question only and itstranslation, identifying the function of rhetorical question based on Larson's concept (1998) and its translation, analyzing the rhetorical questions and its translation by translation techniques applied, and last, analyzing the rhetorical questions translation and the effects of translation techniques to the translation quality in terms of the acceptability level based on the instrument of translation quality by Nababan., et al (2012). Focus group discussion (FGD) is used to get the result of translation quality in terms of acceptability level. The FGD is a discussion with the raters to decide the acceptability level. The raters already have master degree in translation and they also have experiences in assessing the translation quality. In FGD, there are two raters and the researcher involved and the questioner is given to the raters and the researcher to score the acceptability level based on the acceptability instrument assessment by Nababan, et al (2012). 
Table 1

Scale and Information of Acceptability Instrument

\begin{tabular}{c|c|l}
\hline Translation Category & Score & \multicolumn{1}{c}{ Qualitative Parameters } \\
\hline Acceptable & 3 & $\begin{array}{l}\text { Translation is natural: the technical terms used are } \\
\text { commonly used and familiar to the reader: the phrases, } \\
\text { clauses, and sentences used are in conformity with the } \\
\text { Indonesian rules. }\end{array}$ \\
\hline Less Acceptable & 2 & $\begin{array}{l}\text { Generally, the translation has already been natural: but, } \\
\text { there is little problem with the use of technical terms or } \\
\text { a slight grammatical error. }\end{array}$ \\
\hline Unacceptable & 1 & $\begin{array}{l}\text { Translation is not natural or feels like the translation } \\
\text { work: technical terms used are not commonly used and } \\
\text { are not familiar to the reader: the phrases, clauses, } \\
\text { sentences used do not conform to the Indonesian. }\end{array}$ \\
\hline
\end{tabular}

The table following explains the translation quality instrument used in this research:

\section{FINDING}

The finding of this study is there are 14 functions of rhetorical questions found in the novel of Five On A Treasure Island by Enid Blyton, namely: to confirm, to show surprise, emphasize a known fact, to suggest, to persuade, to show uncertainty, to show amazement, to command, to request, to show angry, to show

Table 2

The Functions of Rhetorical Question

\begin{tabular}{c|l|c|c}
\hline No. & Functions of Rhetorical Question & Amount & Percentage \\
\hline 1. & To confirm & 71 & 40 \\
\hline 2. & To show surprise & 35 & 20 \\
\hline 3. & To emphasize a known fact & 13 & 7 \\
\hline 4. & To suggest & 11 & 6 \\
\hline 5. & To persuade & 10 & 6 \\
\hline 6. & To show amazement & 8 & 5 \\
\hline 7. & To show doubt or uncertainty & 8 & 5 \\
\hline 8. & To command & 6 & 3 \\
\hline 9. & To request & 4 & 2 \\
\hline 10. & To show angry & 3 & 2 \\
\hline 11. & To show confusion & 3 & 2 \\
\hline 12. & To introduce a new topic & 2 & 1 \\
\hline 13. & To complain & 2 & 1 \\
\hline 14. & To admonish & 1 & 1 \\
\hline & $\quad$ TOTAL & & $\mathbf{1 0 0}$ \\
\hline
\end{tabular}

confusion, to complain, to introduce a new topic, and to admonish. The function of rhetorical question found is shown in the following table:

From the table 2, it is shown that the function 'to confirm' is the most dominant applied represent the rhetorical question in the novel. Meanwhile, the function 'to admonish' is the most infrequent applied in the novel. From the 14 functions of rhetorical question found in Five On A Treasure Island by Enid Blyton, there are 9 new functions found that have not been identified by Larson (1998) before, namely: to confirm, to suggest, to persuade, to show amazement, to command, to request, to show 
angry, to show confusion, and to complain. The results is congruous to Larson (1998: 259-260) that states rhetorical question has many functions and every language has the list of rhetorical question functions and specific question form which may be used rhetorically. Larson also stated that the functions of rhetorical question in English, as follows:

- To emphasize a known fact

- To indicate doubt or uncertainty

- To introduce a new topic or new aspect of topic

- To show surprise

- To admonish or exhort

- To express the speaker's evaluation
Other finding in this study is the translation quality in terms of the acceptability level. The acceptability level of rhetorical question translation in Five On A Treasure Island is acceptable, yet the score still not getting perfect because there is little problem with the use of technical terms by the translator. The result shows that mostly functions of rhetorical question translation in its Indonesian translation Lima Sekawan Di Pulau Harta have high level of acceptability. However, there are 4 functions that are not getting the perfect score in the acceptability level, namely: to confirm, to show surprise, emphasize a known fact, and to command. It is because that the translator use 


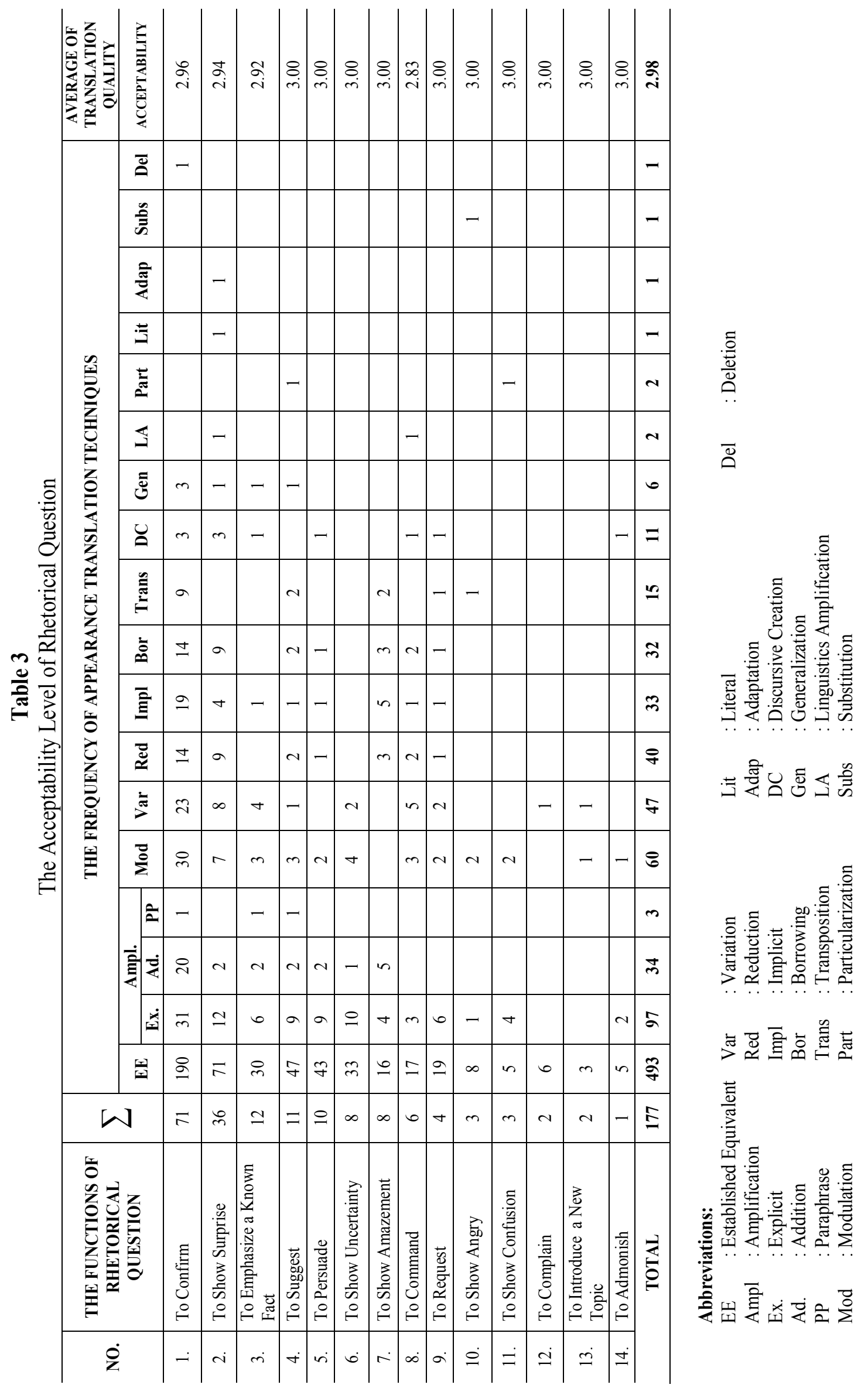


the uncommon technical terms in the target text. The acceptability level of rhetorical questions is shown in the following table:

\section{DISCUSSION}

In this part, it will be discussed the 3 most dominant and the 3 most infrequent function of rhetorical questions applied in Five On $A$ Treasure Island and its Indonesian translation Lima Sekawan Di Pulau Harta.

\section{To confirm}

The function 'to confirm' is the most dominant function applied in conversation by using rhetorical question in Five On A Treasure Island. By using a rhetorical question the speaker wants to verify or reassure the information that gets from the hearer. The example of the function 'to confirm', as follows:

\section{$\underline{\text { Source Text }}$}

Daddy : "Cheer up. I dare say we'll find somewhere else just as good for you. And anyway, Mother and I won't be able to go with you this year. Has Mother told you?"

\section{Anne : "No! Oh, Mother-is it true? Can't you really come with us on our holidays? You always do."}

Mother : "Well, this time Daddy wants me to go to Scotland with him."

\section{$\underline{\text { Target Text }}$}

Ayah : "Jangan sedih dong," kata Ayah membujuk. "Kita pasti masih akan berhasil menemukan tempat berlibur yang sama baiknya. Oya, aku dan Ibu kali ini tidak bisa ikut dengan kalian. Ibu sudah bercerita mengenainya?",

Anne : "Belum," sahut Anne. "Betul itu, Bu? Ibu tidak bisa ikut berlibur dengan kami? Selama ini Ibu selalu bisa."
$I b u$ : "Kali ini Ayah mengajak ke Skotlandia," ujar Ibu.

(001/C1/Bsu1/BSa3)

The context of situation:

Mother told the children that they cannot go holiday to Polseath and Mother does not know the alternative destination for them. Hearing the children cannot go holiday to Polseath, Daddy tried to cheer up them and he used the opportunity to tell the children that this holiday Daddy and Mother will go to Scotland, so the children will go to holiday all by their selves. One of their children, Anne, shocked and tried to reassure the Daddy's statement to her Mother.

From the conversation above and based on the finding of translation quality, the raters evaluated that the utterance "Betul itu, Bu?" is acceptable and the utterance "Ibu tidak bisa ikut berlibur dengan kami?" is acceptable. According to the raters, the using reduction technique of the word "really" in this conversation does not caused the decreasing of acceptability level.

From the table 3, it is shown that the function 'to confirm' get the score 2.96 of the acceptability level which means that in this function there is little mistake by the translator in translating the rhetorical question to the target text. The score is affected by the using of deletion techniques caused the translation is difficult accepted in the target language.

\section{To show surprise}

The function of 'to show surprise' is used to show the expression of the speaker after hearing the information from the hearer. The example of the function 'to show surprise', as follows:

\section{$\underline{\text { Source Text }}$}

George's mother: "What are you going to do this afternoon?"

Anne : "George is going to take us out in a boat 
to see the wreck on the other side of the island."

George's mother : "George is going to take you!

Why-what's come over you? You've never taken a single person before, though I've asked you to dozens of times!"

George's mother : "Well, George, I must say I'm pleased that you want to try and do what your father said."

Target Text

Bibi Fanny: "Apa rencana kalian siang ini?"

Anne : "George mengajak kami berperahu di teluk. Kami hendak dibawanya melihat bangkai kapal karam di sisi pulau sebelah sana."

Bibi Fanny: "George mengajak kalian? Wah, George-mimpi apa kau tadi malam? Selama ini kau tak pernah mau mengajak siapa-siapa kesana, walau sudah cukup sering ku suruh."

Bibi Fanny: "Aku merasa senang bahwa kamu mau berusaha mematuhi kata Ayah." (042/C4/Bsu30/BSa33)

The context of situations:

Aunt Fanny or George's mother asked Julian, Dick, and Anne about what they did in this afternoon. Anne told that George will take them to see the wreck on the other side of the island. Aunt Fanny expressed in surprise what George will to do with her cousins because it never happened before that George will invite someone to walk around the Kirrin Island and Aunt Fanny felt pleased what George did to her cousins.

Based on the finding of translation quality, the raters evaluated that the utterance "Wah, George-mimpi apa kau tadi malam?"'is acceptable. The good choice of diction in the target text by the translator does not affected to the acceptability level.

From the table 3, the function 'to show surprise' gets the score 2.94 of the acceptability level. It is caused by the using of literal technique. The literal technique makes the translation is difficult to understand for the readers.

\section{To emphasize a known fact}

The function 'to emphasize a known fact' is used when the speaker gives a statement of fact. The example of the function 'to emphasize a known fact', as follows:

\section{Source Text}

George's father : "Any more noise like that and I shall keep you all in bed tomorrow! Georgina, keep your cousins quiet."

Julian : "Your father's awfully fierce, isn't he? I'm sorry I made that row. I didn't think."

George : "We'd better do something really quiet. Or he'll keep his word-and we'll find ourselves in bed tomorrow just when to explore the wreck."

$\underline{\text { Target Text }}$

Paman Quentin : "Kalau kalian masih berisik juga, besok harus tinggal di kamar semua."

Julian : “Ayahmu galak sekali, ya? Aku menyesal karena tadi berisik. Aku lupa."

George : "Lebih baik kita melakukan suatu permainan yang tenang. Kalau tidak besok kita akan dihukumnya dan tak boleh keluar. Padahal kita hendak memeriksa kapal karam."

(089/C7/BSu71/BSa74) 
The context of situation:

George, Julian, Dick, and Anne tried a simulation in their room when they will explore the wreck tomorrow, but they did not realize that they make a noise and suddenly George's father came into their room and told to Georgina to keep her cousins quiet. Julian, Dick, and Anne really know that George's father is a bad temperamental and Julian emphasize the fact.

Based on the finding of translation quality, the raters evaluated that the utterance "Ayahmu galak sekali, ya?"is acceptable. The good choice of diction and the defending of the rhetorical question form in the target text by the translator do not affected to the acceptability level.

From the table 3, it is shown that the function 'to emphasize a known fact' gets the score 2.92 of the acceptability level. The raters evaluated that the using of discursive creation technique affected the acceptability level in its Indonesian translation of rhetorical question.

\section{To complain}

The function 'to complain' is used when the speaker give a negative comment of something. The example of the function 'to complain', as follows:

\section{$\underline{\text { Source Text }}$}

George pulled the boat high up on the sand.

Julian : "Why so far up? The tide's almost in, isn't it? Surely it won't come as high as this."

George : "I told you I thought a storm was coming. If one does, the waves simply tear up this inlet and we don't want to lose our boat, do we?"
George menarik perahu sampai jauh ke tengah pasir.

Julian : “Kenapa begini jauh? Sebentar lagi kan sudah pasang tinggi. Tak mungkin air akan sampai di sini."

George : "Kan sudah kukatakan tadi, sebentar lagi akan ada angin ribut. Saat itu ombak akan bergulung-gulung melanda di sini. Dan kita tak kepingin kehilangan perahu, bukan?"

(061/C5/Bsu48/BSa52)

The context of situations:

George, Julian, Dick, and Anne arrived in the Kirrin Island. George pulled the boat far from the edge of the beach. Seeing George pulled the boat, Julian feels that George does not need to pull the boat high up on the sand because the tide is almost in.

Based on the finding of translation quality, the raters evaluated that the utterance "Kenapa begini jauh?"is acceptable. The good choice of diction and the defending of the rhetorical question form in the target text by the translator do not affected to the acceptability level.

From the table 3, the function 'to complain' gets the score 3.00 of the acceptability level. The raters evaluated that the functions 'to complain' are translated well by the translator and the technical terms used in translating the function is appropriated in the target text. In this function, there is no issue about the affected of using the translation technique toward the translation quality in terms of the acceptability level.

\section{To introduce a new topic}

The function 'to introduce a new topic' is used when the speaker wants to begin a conversation

$\underline{\text { Target Text }}$ 
with the hearer. The example of the function 'to introduce a new topic', as follows:

\section{Source Text}

Alf, the fisher-boy, was surprised to see George so early. He was about to go with his father, fishing. He grinned at George.

Alf, the fisher-boy: "You going fishing, too? My, wasn't that a storm yesterday! I thought you'd be caught in it."

George : "We were," said George. "Come on, Tim! Come on!"

\section{$\underline{\text { Target Text }}$}

Alf, anak nelayan yang dimintai tolong memelihara Tim, heran melihat George muncul begitu pagi. Alf saat itu sedang bersiap-siap hendak turun kelaut mengikut iayahnya. Ia nyengir memandang George.

Alf : "Kau juga mau memancing? Wah, bukan main dahsyatnya angin ribut kemarin. Kukira kau terjebak tak dapat pulang."

George : "Memang," jawab George. "Ayoh, Tim! Ayoh ikut aku!"

(093/C8/BSu74/BSa78)

The context of situations:

George, Julian, Dick, and Anne get ready to see the wreck. At the beach, they see Alf was about to go with his father, fishing. Alf feels surprised to see George and he begins a conversation with George.

Based on the finding of translation quality, the raters evaluated that the utterance "Kau juga mau memancing?"is acceptable. The good choice of diction and the defending of the form in rhetorical question in the target text by the translator do not affected to the acceptability level.
From the table 3 , the function 'to introduce a new topic' gets the score 3.00 of the acceptability level. The raters evaluated that the functions 'to introduce a new topic' are translated well by the translator and the technical terms used in translating the function is appropriated in the target text. In this function, there is no issue about the affected of using the translation technique toward the translation quality in terms of the acceptability level.

\section{To admonish}

The function 'to admonish' is used when the speaker gives a critical statement of something. The example of the function 'to admonish', as follows:

\section{$\underline{\text { Source Text }}$}

Anne : "How lovely it will be to wear shorts again. I'm tired of wearing school tunics. I want to wear shorts, or a bathing suit, and go bathing and climbing with the boys."

Mother : "Well, you'll soon be doing it. Remember to put ready any toys or books you want, won't you? Not many please, because there won't be a great deal of room."

\section{$\underline{\text { Target Text }}$}

Anne : "Wah enak! Kita bisa pakai celana pendek lagi. Aku bosan, terusmenerus memakai pakaian seragam sekolah. Aku kepingin memakai celana pendek, atau baju renang. Aku kepingin berenang dan memanjatmanjat dengan Dick dan Julian."

Ibu : "Sebentar lagi semuanya bisa kau lakukan. Tapi jangan lupa menyiapkan alat permainan dan buku-buku yang ingin kalian bawa. 
Jangan banyak-banyak, karena tempatnya tidak banyak untuk itu."

(009/C1/BSu4/BSa7)

The context of situations:

Anne feels really excited because she and her two brothers will go to Kirrin Island. She talks to herself what she and her brothers will do in Kirrin Island while preparing her stuff. Her mother heard what Anne said and she gives a critical comment to Anne that she should not bring many toys or books.

The conversation above is one example of rhetorical questions translation in Five On A Treasure Island which is not translated in question form in target text. The form is changed because the meaning of the utterance in source text will be accepted in target text not in question form but in declarative sentence form. Based on the finding of translation quality, the raters evaluated that the utterance "Tapi jangan lupa menyiapkan alat permainan dan buku-buku yang ingin kalian bawa"is acceptable.

From the table 3, the function 'to admonish' gets the score 3.00 of the acceptability level. The raters evaluated that the functions 'to admonish' are translated well by the translator and the technical terms used in translating the function is appropriated in the target text. In this function, there is no issue about the affected of using the translation technique toward the translation quality in terms of the acceptability level even the data in this function has changed the form in the target text.

\section{CONCLUSION}

Through this study, it reveals that the using of question especially rhetorical question aims to not seek the information from the speaker or the hearer, but it is used to express other intention. In translating the rhetorical question, it is important for the translator to understand the illocution of the question in the source text, whether the function of the question is asking the information or other intention. Last, in translating the rhetorical question it can be translated become rhetorical question in the target text or other form such as, declarative sentence or imperative sentence, it depends on the intention of the rhetorical question in the source text.

\section{REFERENCES}

Al-Fadda, N.A. (2010). The Translation of Rhetorical Question in Hadith from Arabic into English: A Functionalist Perspective. Thesis. King Saud University: Saudi Arabia.

Arfani, S. (2016). Analisis kalimat tanya pada percakapan dalam novel Pride and Prejudice karya Jane Austen. Wanastra, Vol. VIII. No. 2, September 2016. 1-9.

Ellingworth, P. (2013). "When did we see you...?" Translating Rhetorical Question. The Bible Transator, 64(1), 64-74. Doi: 10.1177/0260093513481149.

Larson, M. L. (1998). Meaning-based translation: a guide to cross-language equivalent (2nd edition). New York: University Press of America.

Moleong, L. J. (2005). Metodologi penelitian kualitatif. RemajaKarya: Jakarta.

Nababan, M. R. (2008). Teori menerjemah bahasa Inggris. Kanisius: Yogyakarta.

Nababan, M. R., Ardiana Nuraeni, Sumardiono. (2012). Pengembangan model penilaian kualitas terjemahan. Kajian linguistic dan 